\title{
Penyerapan Ion Logam Cd Dan Cr Dalam Air Limbah Menggunakan Sekam Padi
}

\author{
Nurhasni, Hendrawati, Nubzah Saniyyah \\ Program Studi Kimia FST UIN Syarif Hidayatullah Jakarta
}

\begin{abstract}
Abstrak
Penelitian tentang penyerapan ion logam kadmium dan kromium dalam air limbah menggunakan sekam padi telah dilakukan. Metode yang digunakan adalah metode statis (batch). Dari hasil penelitian didapatkan kondisi optimum penyerapan yaitu pH 5 untuk $\mathrm{Cd}$, dan $\mathrm{pH} 6$ untuk $\mathrm{Cr}$, konsentrasi ion logam $20 \mathrm{mg} / \mathrm{L}$, dan lama pemanasan 2,5 jam. Efisiensi penyerapan pada air limbah multikomponen untuk $\mathrm{Cd}$ adalah $70,42 \%$, sedangkan untuk $\mathrm{Cr}$ adalah $71,55 \%$. Penyerapan ion logam kadmium dan kromium pada kondisi optimum yang diaplikasikan pada air limbah laboratorium kimia PLT UIN Syarif Hidayatullah Jakarta mempunyai efisiensi penyerapan masing-masing adalah $66,45 \%$ untuk Cd dan $49,29 \%$ untuk Cr.
\end{abstract}

Kata kunci: sekam padi, ion logam kadmium, ion logam kromium, air limbah

\begin{abstract}
Studies on the absorption of cadmium and chromium metal ions in wastewater using rice husk has been performed. The method used is a static method (batch). From the results, the optimum conditions for absorption are of $\mathrm{Cd}$ at $\mathrm{pH} 5$ and $\mathrm{pH} 6$ for $\mathrm{Cr}$, the metal ion concentration $20 \mathrm{mg} / \mathrm{L}$, and 2.5 hours while heating. The efficiency of absorption in multicomponent wastewater for $\mathrm{Cd}$ was $70.42 \%$, while for $\mathrm{Cr}$ is $71.55 \%$. Absorption of cadmium and chromium metal ions at optimum conditions which are applied in the chemical laboratory wastewater PLT UIN Syarif Hidayatullah Jakarta, showed has the absorption efficiency and are $66.45 \%$ and $49.29 \%$ for $\mathrm{Cd}$ and $\mathrm{Cr}$ respectively.
\end{abstract}

Keywords: rice husk, the metal ions cadmium, chromium metal ions, wastewater

\section{PENDAHULUAN}

Perkembangan dalam bidang industri di Indonesia pada saat ini cukup pesat. Hal ini ditandai dengan semakin banyaknya industri yang memproduksi berbagai jenis kebutuhan manusia seperti industri kertas, tekstil, penyamak kulit, dan sebagainya. Seiring dengan pertambahan industri tersebut, maka semakin banyak pula hasil sampingan yang diproduksi sebagai limbah. Salah satu limbah tersebut adalah limbah logam berat. Limbah ini akan menyebabkan pencemaran serius terhadap lingkungan jika kandungan logam berat yang terdapat di dalamnya melebihi ambang batas serta mempunyai sifat racun yang sangat berbahaya dan akan menyebabkan penyakit serius bagi manusia apabila terakumulasi di dalam tubuh (Danarto, 2007).

Usaha-usaha pengendalian limbah ion logam belakangan ini semakin berkembang, yang mengarah pada upaya-upaya pencarian metode-metode baru yang murah, efektif, dan efisien (Kundari dan Slamet, 2008). Beberapa metode kimia maupun biologis telah dicoba untuk menghilangkan logam berat yang terdapat di dalam limbah, diantaranya adsorpsi, pertukaran ion (ion exchange), dan pemisahan dengan membran. Proses adsorpsi lebih banyak dipakai dalam industri karena mempunyai 
beberapa keuntungan, yaitu lebih ekonomis dan juga tidak menimbulkan efek samping yang beracun serta mampu menghilangkan bahanbahan organik. Adsorpsi adalah proses akumulasi adsorbat pada permukaan adsorben yang disebabkan oleh gaya tarik antar molekul adsorbat dengan permukaan adsorben. Interaksi yang terjadi pada molekul adsorbat dengan permukaan kemungkinan diikuti lebih dari satu interaksi, tergantung pada struktur kimia masingmasing komponen (Setyaningtyas, 2005).

Penggunaan adsorben konvensional memerlukan biaya operasional dan regenerasi yang relatif lebih mahal (Wiloso, 2003). Adsorben konvensional yang sering digunakan dalam proses adsorpsi adalah alumina, karbon aktif, silika gel, dan zeolit. Adsorben tersebut mempunyai kemampuan adsorpsi yang baik tetapi tidak ekonomis. Dewasa ini sedang digalakkan penelitian mengenai penggunaan adsorben alternatif yang berasal dari alam, karena selain memiliki kemampuan adsorpsi yang baik, adsorben tersebut juga bersifat lebih ekonomis (Jalali, et al., 2002).

Salah satu adsorben yang memiliki prospek yang baik adalah material biologi ataupun limbah pertanian seperti alga (Shengjun dan Holcombe, 1990), limbah apel (Maranon dan Sastre, 1991), sabut kelapa (Low et al., 1997), lumut (Low et al., 1997), eceng gondok (Collen et al., 1999), ampas tebu (Refilda dkk, 2001), dan genjer (Nurhasni, 2002). Di antara beberapa limbah organik tersebut yang menarik adalah penggunaan sekam padi. Hal ini disebabkan sifat sekam padi yang rendah nilai gizinya, tahan terhadap pelapukan, memiliki kandungan abu yang tinggi, bersifat abrasif, menyerupai kandungan kayu, serta memiliki kandungan karbon yang cukup tinggi (Danarto, 2007).

Negara-negara agraris umumnya mempunyai masalah terhadap limbah hasil pertanian karena terbatasnya tempat penumpukan atau tempat pembuangan hasil sampingan tersebut. Hal ini berkaitan dengan ketersediaan limbah sekam padi yang cukup banyak di segala tempat di sekitar penggilingan padi dan pemanfaatan limbah tersebut yang masih terbatas. Bahkan sekam padi merupakan limbah pertanian yang menjadikan beban bagi petani.
Menurut Lembang (1995), pada negaranegara agraris yang telah maju teknologinya, limbah padi ini hampir tidak menjadi masalah bagi lingkungan karena telah dapat dimanfaatkan, antara lain dalam bidang sumber energi, bahan bangunan, industri kimia, pakan ternak, sumber karbon, dan lain-lain.

Dewasa ini keberadaan abu sekam padi di Indonesia belum mendapatkan perhatian, dan hanya terbatas untuk beberapa keperluan sederhana misalnya untuk abu gosok dan media tanaman. Bahkan di beberapa daerah sekam padi dibuang dan dianggap sebagai bahan yang kurang bermanfaat. Padahal, abu sekam padi merupakan bahan yang sangat potensial sebagai bahan penyerap logam berat dalam air, sehingga bisa menjadi alternatif penyelesaian masalah pencemaran lingkungan. Abu sekam padi dapat digunakan sebagai adsorben karena selain merupakan material berpori juga mempunyai gugus aktif yaitu $\mathrm{Si}-\mathrm{O}-\mathrm{Si}$ dan $\mathrm{Si}-\mathrm{OH}$ (Setyaningtyas, 2005).

\section{Tujuan Penelitian}

1. Menentukan kemampuan adsorpsi dari sekam padi untuk menyerap ion logam $\mathrm{Cd}$ dan $\mathrm{Cr}$.

2. Mengetahui kondisi optimum (massa adsorben, $\mathrm{pH}$, konsentrasi ion logam dan lama pemanasan) dari sekam padi dalam menyerap ion logam $\mathrm{Cd}$ dan $\mathrm{Cr}$.

\section{METODE PENELITIAN}

\section{Alat dan Bahan}

Spektroskopi Serapan Atom Analyst 700 (Perkin Elmer), Pengayak listrik, Neraca Analitik, pH meter, oven listrik, shaker batch, glass wool, kertas saring dan peralatan gelas lainnya.

Bahan yang digunakan antara lain $\mathrm{NaOH}, \quad \mathrm{K}_{2} \mathrm{Cr}_{2} \mathrm{O}_{7}, \mathrm{~Pb}\left(\mathrm{NO}_{3}\right)_{2}, \quad \mathrm{CdSO}_{4} . \quad 8 \mathrm{H}_{2} \mathrm{O}$; $\mathrm{CuSO}_{4} \quad .5 \mathrm{H}_{2} \mathrm{O}, \mathrm{HNO}_{3}$ (p.a), larutan buffer, aquadest dan sekam padi (yang didapatkan dari penggilingan padi di Kampung Jati, Tangerang).

\section{Pelaksanaan Penelitian}


Penelitian dilaksanakan dalam tiga tahap. Pertama adalah pembuatan adsorben dari arang sekam padi. Kedua adalah pengujian kemampuan penyerapan ion logam $\mathrm{Cd}$ dan $\mathrm{Cr}$ arang sekam padi dengan variasi massa arang sekam padi, variasi konsentrasi larutan ion logam, variasi $\mathrm{pH}$, serta variasi lama pemanasan untuk mengetahui kondisi optimum dengan menggunakan metode sorpsi batch. Ketiga adalah mengaplikasikannya dengan menggunakan limbah multikomponen dan limbah yang berasal dari PLT UIN Syarif Hidayatullah Jakarta yang didasarkan pada kondisi optimum yang dihasilkan dari tahap sebelumnya.

\section{Pembuatan Adsorben dari Sekam Padi}

Sekam padi dicuci dengan air sampai bersih dan dijemur di bawah terik matahari hingga kering. Lalu sekam padi yang telah bersih tersebut diarangkan pada suhu $250{ }^{\circ} \mathrm{C}$ selama 2,5 jam. Kemudian dihaluskan dan diayak dengan ukuran $212 \mu \mathrm{m}$. Lalu arang yang dihasilkan disimpan untuk digunakan dalam proses adsorpsi logam berat.

\section{Penentuan Kondisi Optimum Penyerapan}

\section{Pengaruh Massa Sekam Padi Terhadap Penyerapan Ion Logam Cd dan $\mathrm{Cr}$}

Adsorben dengan ukuran partikel 212 $\mu \mathrm{m}$ ditimbang masing-masing 0,$5 ; 1,0$; dan 1,5 gram. Lalu ditambahkan larutan ion logam sebanyak $10 \mathrm{~mL}$ dengan konsentrasi 20 ppm dan dishaker selama 30 menit dengan kecepatan putaran $180 \mathrm{rpm}$. Setelah itu disaring dan filtrat yang dihasilkan ditampung dan ditepatkan volumenya $10 \mathrm{ml}$ dengan aquadest, ditambah 1 tetes asam nitrat dan diukur dengan SSA.

\section{Pengaruh Konsentrasi Ion Logam Terhadap Penyerapan Ion Logam Cd dan $\mathrm{Cr}$}

Adsorben dengan ukuran partikel 212 $\mu \mathrm{m}$ ditimbang masing-masing 0,5 gram, lalu ditambahkan larutan ion logam sebanyak 10 $\mathrm{mL}$ dengan variasi konsentrasi 20, 40, 60, 80, dan 100 ppm. Kemudian dishaker selama 30 menit dengan kecepatan putaran $180 \mathrm{rpm}$. Setelah itu disaring dan filtrat yang dihasilkan ditampung dan ditepatkan volumenya $10 \mathrm{ml}$ dengan aquadest, ditambah 1 tetes asam nitrat dan diukur dengan SSA.

\section{Pengaruh pH Ion Logam Terhadap Penyerapan Ion Logam Cd dan Cr}

Adsorben dengan ukuran partikel 212 $\mu \mathrm{m}$ ditimbang masing-masing 0,5 gram, lalu ditambahkan $10 \mathrm{~mL}$ larutan ion logam dengan konsentrasi $20 \mathrm{ppm}$ dengan variasi $\mathrm{pH} \mathrm{3,} \mathrm{4,} \mathrm{5,} \mathrm{6,} \mathrm{dan} \mathrm{7.} \mathrm{Kemudian} \mathrm{dishaker}$ selama 30 menit dengan kecepatan putaran 180 rpm. Setelah itu ditampung dan ditepatkan volumenya $10 \mathrm{ml}$ dengan aquades $\mathrm{pH}$ yang sama, dan ditambah 1 tetes asam nitrat p.a dan diukur dengan SSA.

\section{Pengaruh Lama Pemanasan Terhadap Penyerapan Ion Logam Cd dan $\mathrm{Cr}$}

Ditimbang masing-masing 0,5 gram sekam padi dengan ukuran partikel $212 \mu \mathrm{m}$, lalu dipanaskan pada suhu $250{ }^{\circ} \mathrm{C}$ dengan variasi lama pemanasan: 1,$5 ; 2 ; 2,5$; dan 3 jam. Lalu ditambahkan larutan ion logam dengan konsentrasi 20 ppm. Kemudian dishaker selama 30 menit dengan kecepatan putaran $180 \mathrm{rpm}$. Setelah itu disaring, dan filtrat yang dihasilkan ditampung dan ditepatkan volumenya $10 \mathrm{~mL}$ dengan aquades. Lalu ditambah 1 tetes asam nitrat p.a. dan diukur dengan SSA.

\section{Penyerapan Limbah Multikomponen}

Adsorben dengan ukuran partikel 212 $\mu \mathrm{m}$ ditimbang masing-masing dengan berat 0,5 gram, lalu ditambahkan $10 \mathrm{~mL}$ larutan ion logam multikomponen (dengan konsentrasi dan $\mathrm{pH}$ pada kondisi optimum) Kemudian dishaker selama 30 menit dengan kecepatan putaran 180 rpm. Setelah itu ditampung dan ditepatkan volumenya $10 \mathrm{ml}$ dengan aquadest yang kondisinya sama dengan larutan ion logam yang ditambahkan. lalu ditambahkan 1 tetes asam nitrat p.a dan diukur dengan SSA.

\section{Penyerapan Limbah PLT}

Adsorben dengan ukuran partikel $212 \mu \mathrm{m}$ ditimbang masing-masing dengan berat 0,5 gram, lalu ditambahkan $10 \mathrm{~mL}$ larutan ion logam 
yang berasal dari limbah PLT dengan $\mathrm{pH}$ yang telah diatur sesuai dengan kondisi optimum. Kemudian dishaker selama 30 menit dengan kecepatan putaran $180 \mathrm{rpm}$. Setelah itu ditampung dan ditepatkan volumenya $10 \mathrm{ml}$ dengan aquadest yang kondisinya sama dengan larutan limbah yang ditambahkan. lalu ditambahkan 1 tetes asam nitrat p.a dan diukur dengan SSA.

\section{HASIL DAN PEMBAHASAN}

\section{Pembuatan Adsorben}

Adsorben dibuat melalui proses karbonisasi sekam padi dalam tungku pembakar "furnace" pada suhu $250{ }^{\circ} \mathrm{C}$. Besarnya suhu yang digunakan dalam penelitian ini berdasarkan hasil penelitian yang dilakukan oleh Seleng (1997). Pada penelitian Asyar, dkk (1996) juga menunjukkan bahwa penggunaan suhu pada proses karbonisasi di atas $250{ }^{\circ} \mathrm{C}$ menyebabkan hasil adsorben yang didapat semakin sedikit. Hal ini disebabkan karena pada suhu rendah sebagian besar sekam padi terbakar menjadi karbon (arang). Sedangkan pada suhu yang lebih tinggi sebagian arang tersebut terbakar lebih lanjut sehingga berubah menjadi abu. Jadi, makin tinggi suhu pembakaran, maka semakin besar bagian sekam yang berubah menjadi abu. Oleh sebab itu berat arang hasil karbonisasi semakin berkurang.

Sebelum dilakukan karbonisasi, terlebih dahulu sekam padi dicuci dengan air bersih untuk membebaskan kotoran-kotoran yang mungkin menempel pada sekam padi. Setelah dicuci bersih, dilakukan proses pengeringan untuk mengeliminasi kandungan air dalam sekam padi dengan cara menguapkan air dari permukaan sekam padi. Proses pengeringan ini diikuti oleh pengurangan volume. Menuut Harsono (2002) laju pengeringan menurun seiring dengan penurunan kadar air selama penguapan dan berlangsungnya proses pengeringan tidak terjadi dalam suatu waktu sekaligus.

Setelah didapatkan arang sekam padi, maka arang tersebut diayak menggunakan ayakan berukuran $212 \mu \mathrm{m}$. Hal ini disebabkan karena efisiensi penyerapan adsorben terhadap adsorbat sangat dipengaruhi oleh ukuran partikel adsorben. Secara teoritis efisiensi penyerapan akan semakin meningkat dengan semakin kecilnya ukuran partikel. Hal ini disebabkan karena bertambahnya luas permukaan adsorben, sehingga ion-ion akan lebih banyak terserap pada permukaan biosorben tersebut (Sunarya, 2006).

\section{Pengaruh Massa Sekam Padi Terhadap Penyerapan Ion Logam Cd dan Cr}

Untuk melihat pengaruh variasi jumlah adsorben digunakan konsentrasi untuk masingmasing larutan ion logam sebesar $20 \mathrm{ppm}$. Dan variasi massa adsorben yang diujikan adalah 0,5 ; 1,0 ; dan $1,5 \mathrm{~g}$.

Adsorpsi dilakukan dalam sistem batch menggunakan shaker (pengguncang). Proses adsorpsi dilakukan pada suhu ruang, yaitu $26^{\circ} \mathrm{C}$. pemilihan suhu ruang ini karena proses adsorpsi pada suhu yang semakin tinggi menyebabkan ion logam berat yang terserap oleh adsorben semakin sedikit. Hal ini terjadi karena semakin tinggi suhu pada proses adsorpsi, maka pergerakan ion semakin cepat sehingga jumlah ion logam berat yang terserap oleh adsorben semakin berkurang (Kundari dan Slamet, 2008).

Gambar 1 menunjukkan bahwa penyerapan ion logam secara maksimum terjadi pada massa sekam padi $1,5 \mathrm{~g}$ dengan efisiensi penyerapan untuk ion logam berat $\mathrm{Cd}$ dan $\mathrm{Cr}$ masing-masing sebesar $36,10 \%$ dan $70,78 \%$. Semakin besar massa sekam padi yang digunakan, maka efisiensi penyerapannya

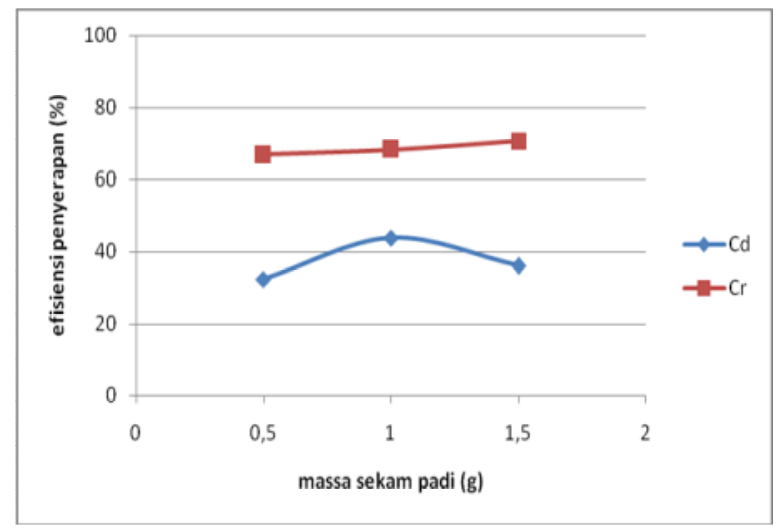

Gambar 1. Pengaruh variasi massa sekam padi terhadap ion logam $\mathrm{Cd}$ dan $\mathrm{Cr}$. 
terhadap ion logam semakin besar. Bertambahnya berat sekam padi sebanding dengan bertambahnya jumlah partikel dan luas permukaan sekam padi sehingga menyebabkan jumlah tempat mengikat ion logam juga bertambah dan efisiensi penyerapan pun meningkat (Refilda, 2001).

\section{Pengaruh pH larutan ion logam}

Kemampuan penyerapan suatu sorben dapat dipengaruhi oleh $\mathrm{pH}$ larutan. Hal ini berhubungan dengan protonasi atau deprotonasi permukaan sisi aktif dari sorben (Nurhasni, 2002). Menurut Riapanitra (2006) pH akan mempengaruhi muatan permukaan adsorben, derajat ionisasi dan spesi apa saja yang dapat terserap dalam adsorpsi tersebut. Nilai $\mathrm{pH}$ juga dapat mempengaruhi kesetimbangan kimia, baik pada adsorbat maupun pada adsorben. Dalam variasi $\mathrm{pH}$ ini kemungkinan ikatan kimia antara adsorben dengan adsorbat dapat terjadi (Refilda, 2001).

Dari gambar 2 terlihat bahwa penyerapan optimum ion logam $\mathrm{Cd}$ adalah pada pH 5, dan ion logam $\mathrm{Cr}$ pada $\mathrm{pH}$ 6. Dengan nilai efisiensi penyerapan untuk ion logam $\mathrm{Cd}$ dan $\mathrm{Cr}$ masing-masing sebesar 64,93\%; 93,33\%.

Pada $\mathrm{pH}$ rendah penyerapan terhadap semua ion logam rendah. Hal ini dikarenakan pada $\mathrm{pH}$ rendah permukaan adsorben dikelilingi oleh ion $\mathrm{H}^{+}$(karena gugus fungsi yang terdapat pada adsorben terprotonasi). Dalam kondisi asam permukaan adsorben juga bermuatan positif, yang akan menyebabkan terjadi tolakan antara permukaan adsorben dengan ion logam, sehingga adsorpsinya pun menjadi rendah (Sembiring, 2009).

Pada $\mathrm{pH}$ netral efisiensi penyerapan juga menurun. Hal ini disebabkan karena pada $\mathrm{pH}$ netral ion-ion logam dapat mengalami reaksi hidrolisis dalam larutan sehingga ia tidak stabil dalam bentuk ion logam semula dan menyebabkan kemampuan sekam padi untuk menyerapnya menurun. Sedangkan pada $\mathrm{pH}$ basa, ion-ion logam dapat membentuk endapan hidroksida sehingga efisiensi penyerapannya sukar untuk ditentukan (Refilda, dkk., 2001; Utomo et al., 2006).

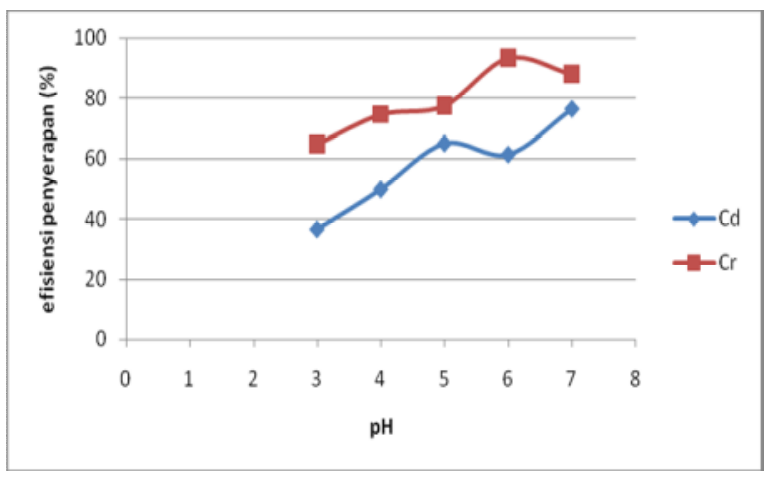

Gambar 2. Pengaruh $\mathrm{pH}$ ion logam $\mathrm{Cd}$ dan $\mathrm{Cr}$ terhadap efisiensi penyerapan sekam padi.

\section{Pengaruh Konsentrasi Ion Logam}

Volume larutan ion logam yang digunakan dalam penelitian ini sebanyak $10 \mathrm{~mL}$. Pemilihan volume ini didasarkan pada asumsi Refilda, dkk (2001), yaitu jika digunakan jumlah ion logam yang lebih banyak akan menyebabkan permukaan sekam padi menjadi lebih cepat jenuh.

Gambar 3 menunjukkan konsentrasi ion logam terhadap efisiensi penyerapan sekam padi. Dari gambar tersebut terlihat bahwa kondisi optimum penyerapan dicapai pada konsentrasi $20 \mathrm{ppm}$, dengan efisiensi penyerapan untuk ion logam Cd dan Cr masing-masing sebesar 68,26\% dan $87,76 \%$. Dengan meningkatnya konsentrasi ion logam, efisiensi penyerapan pun menjadi berkurang, dikarenakan kemampuan menyerap sekam padi terhadap ion logam berat $\mathrm{Cd}$ dan $\mathrm{Cr}$ sudah maksimum. Dengan kata lain kapasitas serap maksimum sekam padi telah tercapai pada konsentrasi 20 ppm (Kundari dan Slamet, 2008).

Menurut Refilda, dkk (2001) penurunan efisiensi penyerapan disebabkan karena pada konsentrasi yang lebih tinggi, jumlah ion logam dalam larutan tidak sebanding dengan jumlah pertikel sekam padi yang tersedia sehingga permukaan sekam padi akan mencapai titik jenuh dan efisiensi penyerapan pun menjadi menurun.

Kedua pendapat tersebut sesuai dengan teori Langmuir yang menjelaskan bahwa pada permukaan adsorben terdapat situs aktif yang jumlahnya sebanding terhadap luas permukaan adsorben, sehingga bila situs aktif pada permukaan dinding sel adsorben telah jenuh oleh ion logam, maka penambahan konsentrasi tidak 
lagi dapat meningkatkan kemampuan adsorpsi dari adsorben tersebut. Oleh sebab itu, pada konsentrasi lebih dari 20 ppm, adsorpsi ion logam mengalami penurunan (Sembiring dkk., 2008).

Menurut Wijayanti (2009) bila permukaan sudah jenuh atau mendekati jenuh terhadap adsorbat, dapat terjadi dua hal:

a) Terbentuk lapisan adsorpsi kedua dan seterusnya di atas adsorbat yang telah terikat di permukaan, gejala ini disebut adsorpsi multilayer.

b) Tidak terbentuk lapisan kedua dan seterusnya sehingga adsorbat yang belum teradsorpsi berdifusi keluar pori dan kembali ke arus fluida.

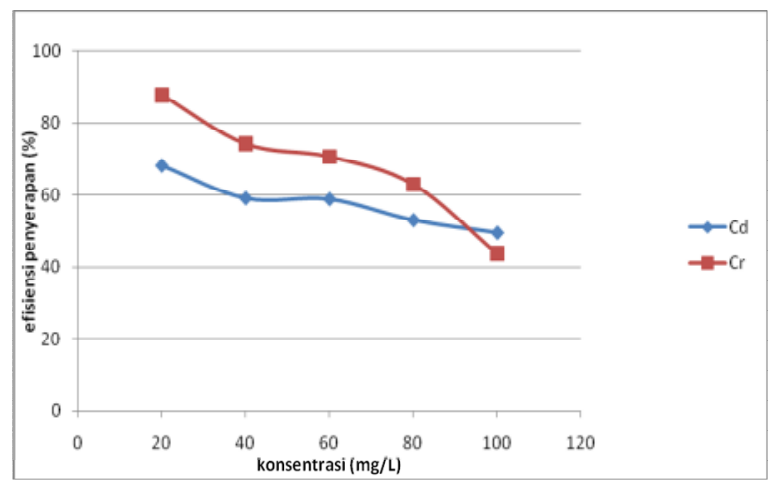

Gambar 3. Pengaruh konsentrasi ion logam $\mathrm{Cd}$ dan $\mathrm{Cr}$ terhadap efisiensi penyerapan sekam padi.

\section{Pengaruh Lama Pemanasan}

Pemanasan sorben dapat meningkatkan kemampuan penyerapan terhadap adsorbat. Pemanasan yang dilakukan dapat memperbesar pori-pori adsorben sehingga akan meningkatkan efisiensi penyerapan (Nurhasni, 2002).

Diketahui bahwa suhu karbonisasi berpengaruh terhadap keaktifan adsorben, semakin tinggi suhu makin rendah daya serapnya. Hasil penelitian menunjukkan karbonisasi sekam pada suhu di atas $250{ }^{\circ} \mathrm{C}$ diperoleh adsorben dengan daya adsorpsi yang sangat rendah. Hal ini dapat dijelaskan karena pada suhu di atas $250{ }^{\circ} \mathrm{C}$ sebagian besar sekam padi diubah menjadi abu sekam. Abu sekam banyak mengandung senyawa silika. Senyawa ini memiliki daya serap rendah dibandingkan karbon karena kurang pori pada permukaan partikel (Asyar dkk., 1996).

Pada penelitian ini dilakukan proses karbonisasi pada suhu $250{ }^{0} \mathrm{C}$ dengan variasi lamanya pemanasan. Dari gambar 4 terlihat bahwa kondisi optimum penyerapan sekam padi rata-rata dicapai pada pemanasan $250{ }^{\circ} \mathrm{C}$ selama 2,5 jam. Sedangkan untuk pemanasan lebih lama lagi efisiensinya mulai menurun, hal ini disebabkan karena terjadinya perubahan struktur dari sekam padi tersebut.

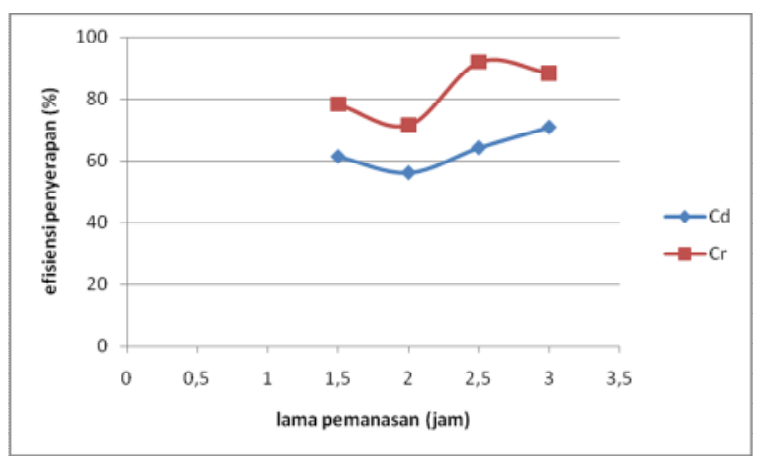

Gambar 4. Pengaruh lama pemanasan sekam padi terhadap penyerapan ion logam $\mathrm{Cd}$ dan $\mathrm{Cr}$.

\section{Pengaruh Interaksi Larutan Multikomponen}

Pengaruh interaksi larutan multikomponen dilakukan dengan tujuan untuk mengetahui kompetisi logam yang terserap pada permukaan sekam padi. Limbah multikomponen yang digunakan dibuat secara simulasi berdasarkan kondisi optimum yang didapat dari data penentuan kondisi optimum sebelumnya masing-masing ion logam. Dari tabel 1 terlihat bahwa penyerapan sekam padi terhadap larutan multikomponen memberikan efisiensi penyerapan yang sangat baik. Hal ini menunjukkan bahwa sekam padi dengan kondisi optimum yang diperoleh merupakan suatu adsorben yang sangat baik untuk digunakan sebagai bahan penyerap.

Nilai kapasitas penyerapan yang dihasilkan juga cukup baik. Kapasitas adsorpsi arang aktif bergantung pada karakteristik arang aktifnya, seperti: tekstur (luas permukaan, distribusi ukuran pori), kimia permukaan (gugus fungsi pada permukaan), dan kadar abu. Selain itu juga bergantung pada karakteristik adsorpsi: 
bobot molekul, polaritas, pKa, ukuran molekul, dan gugus fungsi. Kondisi larutan juga berpengaruh, seperti: $\mathrm{pH}$, konsentrasi, dan adanya kemungkinan adsorpsi terhadap zat lain (Villacarias, 2005).

Tabel 1. Hasil penyerapan sekam padi terhadap larutan multikomponen

\begin{tabular}{c|ccc}
\hline No & $\begin{array}{c}\text { Ion } \\
\text { Logam }\end{array}$ & $\begin{array}{c}\text { Efisiensi } \\
\text { Penyerapan (\%) }\end{array}$ & $\begin{array}{c}\text { Kapasitas } \\
\text { Penyerapan } \\
\text { (mg/g) }\end{array}$ \\
\hline 1. & $\mathrm{Cd}$ & 70,42 & 0,4868 \\
2. & $\mathrm{Cr}$ & 71,55 & 0,2370 \\
\hline
\end{tabular}

\section{Aplikasi}

Penyerapan sekam padi terhadap ion logam dalam air limbah Pusat Laboratorium Terpadu (PLT) Universitas Islam Negeri Syarif Hidayatullah Jakarta khususnya laboratorium kimia analitik, diperoleh kadar ion logam seperti terdapat dalam tabel 2.

Tabel 2. Hasil penyerapan sekam padi terhadap ion logam dalam air limbah PLT UIN Syarif Hidayatullah Jakarta

\begin{tabular}{c|ccc}
\hline No & $\begin{array}{c}\text { Ion } \\
\text { Logam }\end{array}$ & $\begin{array}{c}\text { Efisiensi } \\
\text { penyerapa } \\
\text { n(\%) }\end{array}$ & $\begin{array}{c}\text { Kapasitas } \\
\text { penyerapan } \\
(\mathbf{m g} / \mathrm{g})\end{array}$ \\
\hline 1. & $\mathrm{Cd}$ & 66,45 & $4,2 \times 10^{-3}$ \\
2. & $\mathrm{Cr}$ & 49,29 & $8,4 \times 10^{-3}$ \\
\hline
\end{tabular}

Efisiensi masing-masing ion logam $\mathrm{Cd}$ 66,45 dan $\mathrm{Cr} 49,29 \%$.

\section{Isoterm Adsorpsi}

Isoterm Langmuir merupakan proses adsorpsi yang berlangsung secara kimisorpsi satu lapis. Menurut Langmuir dalam Amri (2004), pada permukaan adsorben terdapat situs-situs aktif bersifat homogen yang proporsional dengan luas permukaan. Masing-masing situs aktif hanya dapat mengadsorpsi satu molekul adsorbat saja sehingga adsorpsi hanya akan terbatas pada pembentukan lapisan tunggal (monolayer), sedangkan isoterm freundlich merupakan proses adsorpsi yang terjadi secara fisisorpsi banyak lapisan.

Gambar 5 menunjukkan grafik isoterm Langmuir. Terlihat bahwa grafik yang diperoleh adalah grafik linier dengan persamaan $y=a+b x$, dengan nilai koefisien korelasi $\left(\mathrm{R}^{2}\right)$ mendekati 1 , sehingga dapat dikatakan bahwa data-data yang diperoleh dari penelitian ini sesuai dengan model kesetimbangan adsorpsi Langmuir.

Gambar 6 menunjukkan grafik isoterm Freundlich. Dari kedua grafik isoterm logam Cd, dapat dilihat bahwa perbandingan nilai koefisien korelasi $\left(\mathrm{R}^{2}\right)$ dari persamaan kesetimbangan adsorpsi Langmuir dan Freundlich mendekati 1, yaitu 0,950 untuk isotherm Langmuir dan 0,986 untuk isotherm Freundlich. Dari nilai $\mathrm{R}^{2}$ tersebut dapat diketahui model persamaan kesetimbangan mana yang dapat mewakili reaksi yang terjadi pada penelitian ini. Nilai $\mathrm{R}^{2}$ dari model freundlich lebih mendekati 1 dibandingkan model isoterm Langmuir. Hal ini menunjukkan bahwa data-data yang diperoleh lebih mengikuti model persamaan kesetimbangan adsorpsi Freundlich. Hal juga diperkuat oleh nilai energi adsorpsi, yakni $\quad \mathrm{E}=-6,330 \mathrm{~kJ} / \mathrm{mol}$. Nilai adsorpsi ini diperoleh dengan cara mensubtitusikan nilai $\mathrm{K}$ (yang ditentukan dari grafik isoterm di atas) ke dalam persamaan $\mathrm{E}=-\Delta \mathrm{G}^{0}=\mathrm{RT} \ln \mathrm{K}$ (Sembiring, dkk., 2008).

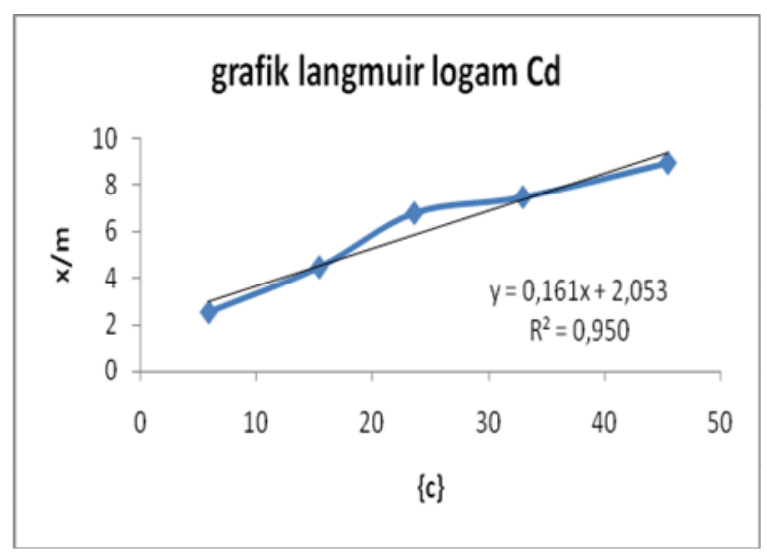

Gambar 5. Grafik Langmuir 


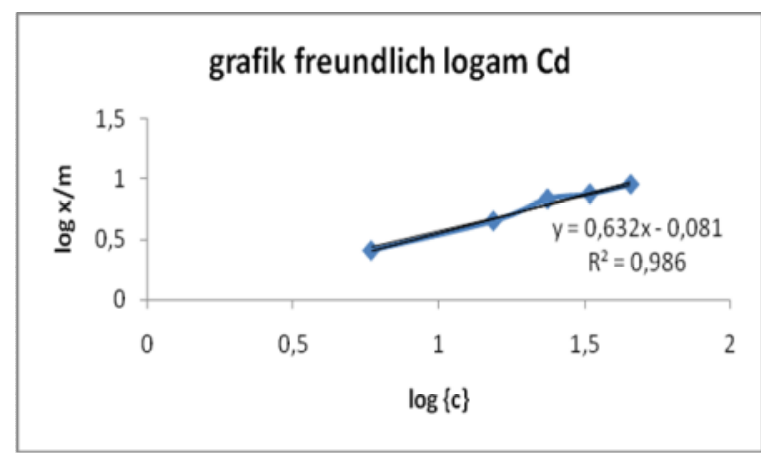

Gambar 6. Grafik Freundlich

Gambar 7 dan 8 menunjukkan grafik isoterm adsorpsi dari ion logam $\mathrm{Cr}$. Hasil

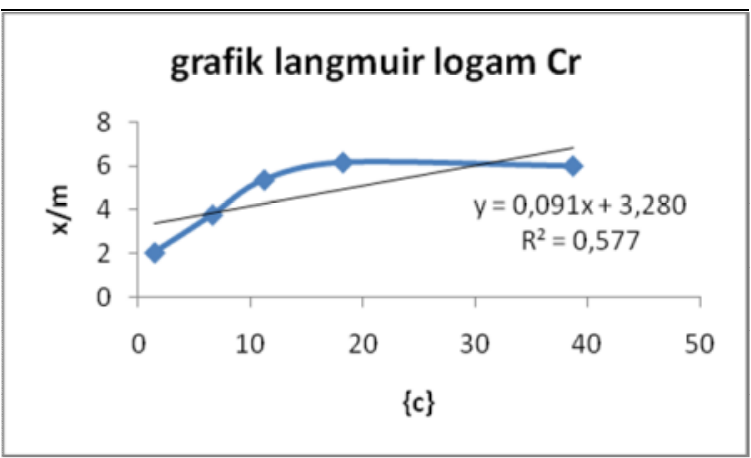

Gambar 7. Grafik Langmuir

isoterm adsorpsi dari ion logam $\mathrm{Cr}$ mengikuti hasil isoterm adsorpsi dari ion logam $\mathrm{Cd}$. Akan tetapi nilai koefisien korelasi $\left(\mathrm{R}^{2}\right)$ dari grafik

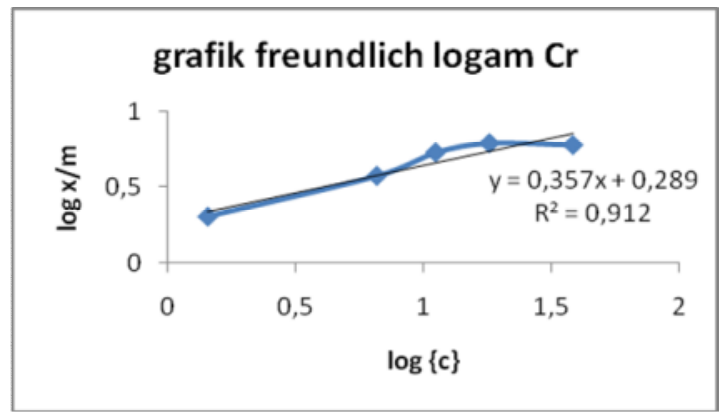

Gambar 8. Grafik Freundlich

isoterm Langmuir jauh dari 1, yaitu 0,577 sedangkan nilai koefisien korelasi dari isoterm Freundlich sebesar 0,912. Hal ini menunjukkan bahwa data-data yang diperoleh dari penelitian ini tidak sesuai dengan model kesetimbangan adsorpsi Langmuir. Nilai energi adsorpsi yang di dapat adalah $E=-8,9116 \mathrm{~kJ} / \mathrm{mol}$. Nilai (-) menunjukkan bahwa proses biosorpsi berlangsung spontan dan bersifat eksoterm (Diantariani dkk., 2008).

\section{KESIMPULAN DAN SARAN}

Setelah melakukan penelitian ini maka dapat disimpulkan bahwa:

1. Dari keempat formulasi, formulasi II memiliki kandungan karbofuran yang paling tinggi, yaitu sebesar 3,801\% dari penambahan karbofuran semula sebesar $5 \%$ sehingga didapatkan yield sebesar $76,02 \%$.

2. Sebelum digunakan sebagai adsorben, zeolit terlebih dahulu dipreparasi dan diaktivasi, sehingga interaksi antar spesi menjadi aktif pada saat proses adsorpsi.

\section{Saran}

Untuk mendapatkan hasil yang lebih akurat, maka diperlukan pengujian lebih lanjut seperti pengujianformulasi penglepasan terkendal dalam air dan juga pengujian formulasi penglepasan terkendali bahan aktif karbofuran di lahan pertanian.

\section{DAFTAR PUSTAKA}

1. Anonim. 1975. Furadan, Systemic Broad Spectrum Carbamate Insecticide-NematicideMulticide. Technical bulletin I Niagara Chemical Division, FMC Corporation. New York.

2. Anonim. 1976. Carbofuran Data Summary. Furadan Insecticide-Nematicide. FMC Corporation

3. Anonim. 1988. Pestisida Untuk Pertanian dan Kehutanan. Direktorat Perlindungan Tanaman Pangan. Jakarta

4. Aspiyanto. 1993. Mengenal Shellak. Buletin Ekonomi Bapindo 18(3):19-21 
5. BATAN. 2005. Keputusan Kepala BATAN No. 392/KA/XI/2005. Tentang Organisasi dan Tata Kerja BATAN: Jakarta

6. Chairul, Sofnie. M. 2003. Pengujian Formulasi Lepas Terkendali Herbisida 2,4-D Terhadap Gulma Tanaman Padi. Dalam: Semiloka Nasional Himpunan Kimia Indonesia. Jakarta

7. Cook, R.F. 1973. Carbofuran. Analytical Methods for Pesticides and Plant Growth Regulators. Thin Layer and Liquids Chromatography and Analysis of International Importance. Academic Press Inc. New York

8. Dyer, A. 1988. an introduction to zeolite molecular sieves. Jhon Wiley \& Sons Ltd. Department of chemistry \& applied chemistry, University of Salford: UK

9. Getzin, L.W.1973. Persistance and Biodegradation of Carbofuran in Soils. J.Agric. chem. 2(3):287-291

10. Harris, F.W. 1975. Controlled Release Herbicide Polymers Formulation in Aquatic Weed Control. Hyacinth control

11. Hay, R.L. 1996. Zeolites and Zeolitic Reaction in Sedimentary Rocks. Dept. Geology and Geophysics. University of California, Berkeley

12. Hendayana, S. 2002. Materi Pokok Kimia Analitik Instrument. Jakarta: Universitas Terbuka

13. Hermanto, S. 2008. Mengenal Lebih Jauh Teknik Analisa Kromatografi dan Spektrofotometri. Jakarta: Pusat Lab Terpadu UIN Syarif Hidayatullah

14. Homeyer, B. 1975. Curaterr a Broad Spectrum Root Systemic Insecticide and Nematicide. Pflanzenchutz Nachrichten Bayer

15. Hussain, M. 1989. Controlled-Release Formulatins of Pesticides. IAEA, Vienna, Austria

16. Khopkar, S. M. 2003. Konsep Dasar Kimia Analitik. Jakarta: UI Press

17. Le Baron, H.M. and J. Gressel (Eds). 1982. Herbicides Resistence in Planta. A. Willey \& Sons, New York
18. Mulyadi. 1989. Residu Insektisida Karbofuran dalam Tanaman Padi. Sekolah Tinggi Teknologi Tekstil. Bandung

19. Munifah, I. 2005. Petunjuk Praktikum Teknik Instrumentasi Kimia. Jakarta: UIN

20. Putra, EDL.2004. Kromatografi Cair Kinerja Tinggi Dalam Bidang Farmasi. Jurusan Farmasi Fakultas Teknologi dan Ilmu Pengetahuan Alam Universitas Sumatera Utara

21. Saputra, R. 2006 Paper Pemanfaatan Zeolit Sintesis Sebagai Alternatif Pengolahan Limbah Industri. Hal 1-8

22. Soerjani, M. 1987. Formulasi Herbisida Lepas Terkendali, Suatu Upaya Efikasi dan Efisiensi. Lingkungan dan Pembangunan. No. 7(3): 1-4

23. Sumaryono dan T. Hutabarat. 1988. Pola Pelepasan 2,4-D dari Formulasi Herbisida Lepas Lambat Menggunakan Matres Karet Alam. Dalam: Prosiding Konf. IX. HIGI. Bogor

24. Venkateswarl, K., T.K. Siddarame Gowda and N. Sethunathan. 1977. Persistence and Biodegradation of Carbofuran in Flooded Soils. J. Agric. Food chem.. 23(3):533-535 
